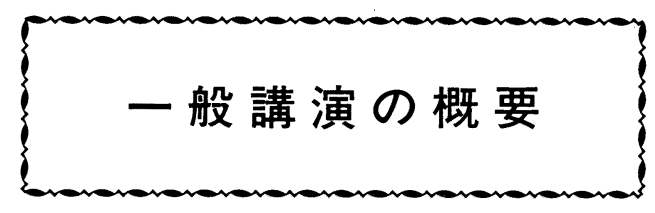

10 月 16 日，17 日の両日にわたり，分科会方式で抄 紙, パルプ, 総合技術の 3 セッションについて 31 件の 講演が行われた。

以下に発表内容の概要を司会者の方に紹介して頂い た。

抄紙セッションA

司会 神崎製紙侏研究開発本部

生産技術部長 本間 正嗣

\section{A-1．YN マシンの操業経験}

山陽国策パルプ株勇払工場 大熊 紘治

新聞用紙は増ページによる需要の伸びと併せて高速 オフセット化, 用紙軽量化, カラー化など要求される 品質も多様化してきている。同社ではこれらのニーズ に対応する設備として，勇払士場に 2 台目の新聞用紙 マシンであるYN マシンを完成させた。

ここでは設備の設計思想として, (1)原料調成系から マシンまでの一貫設備, (2)導入設備の徹底的な検討, (3)上質紙ノウハウの導人を挙げ, 現時点で最良と考え られる設備を装備した YN マシンについて, 個々の設 備の特徵に触れながらその操業性に言及している。

採用した設備は, (1)白水回収装置として国内初であ り, 1 台で大容量の処理が可能なセンターディスク フィルター, (2)ベルベフォーマーとの組合せが最適と 考えられるコンバーフローヘッドボックス, (3)ワイ ヤーは表裏差コントロールが容易で軽量紙抄造に適し たベルベIII M 型, (4)プレスは BM 計とスチームボッ クスをリンクさせて水分プロファイル制御を行い, 振 動対策として制振装置を装備したトライベントプレ ス +4 P 構成, (5)゙ライヤーパートは初期群にシート 走行性を優先させたベルランドライヤー及びブロー ボックスを，その他，低差压でもドレン排出が可能な 固定式サイフォン, 補助乾燥装置としてのユニフロー ポケットベンチレーター, (6)カレンダーにはボトム ロールの電磁誘導加熱コイルと BM 計をリンクさせ, 紙厚自動制御が可能なオープン型 6 段バーサニップ, (7)リールは巻固さコントロール及び全自動枠替えの可 能なサーフェスリール，8ワインダーには自動通紙装
置, 自動枠替え装置, 自動位置決めスリッター装置な ど寸法精度や作業能率向上を目的とした付帯設備を具 備，等々である。

最後に，すべての工程管理を中央操作室 CRT上で 行い，可能なかきりりの自動化・省力化・最適化を図っ た操業管理システムについての説明があり，今後の方 向性では, 装置産業操業の原点である設備保全を主体 とした技術力向上を示唆した発表であった。

\section{A-2． N-1 マシンソフトカレンダーの操業経験 十條製紙(侏)八代工場 音羽徹}

ソフトカレンダーは低密度, 高平滑, 高光沢などの 印刷適性に寄与する紙を生産する設備として, 近年注 目を浴びている。同社では八代工場 N-1 マシン設置に 際し, 高速幅広マシンで初めての導入を四った。

以下，ソフトカレンダーの設備概要を紹介すると共 に, 操業経験, 紙品質の特徵について総説している。

設備概要では， 2 スタック， 2 段 1 ニップで構成れ れたソフトカレンダーの配置闵を示しながら, (1) 3 種 類のソフトロールカバー材質の選択, (2)赤外線温度測 定装置によるソフトロールの温度管理, (3)ソフトロー ルの冷風装置及びエアーシャワーによるロール両端部 の加熱防止対策，(4)バリオスイミングロール油圧調整 によるニッププロファイル制御，(5) BM 計とリンクさ せたヒーティングロールサーマジェットによるキャリ パープロファイル制御， (6)フトロール損傷防止のた めのインターロック機能について解説した。

操業経験については, (1)カレンダー入口エキスパン ダーロール撤去および 3 本よりキャリアロープによる 通紙性の改善, (2)ソフトールにガラス繊維入り樹脂, ヒーティングロールには燐青銅としたドクターブレー ド材質の選定, (3)前裹の同期加圧用油圧連絡配管によ るロール保護対策, (4)バリオスイミングロールの実際 の油圧と計算による油圧との誤差を修正するフィード バック制御の導入，(5)ソトロールカバー材質による 操業性の違い及びトラブル事例, (6) ヒーティングロー ル両端部の曲線カーブ研磨による発熱变形対策, 等々 を詳説した。

紙品質に関しては, (1)チルドロールとソフトロール 
の比較を行い, 印面濃度・印面光沢・表裏差における ソフトロールの優位性を, (2)ソフトロールカバー材質 による比較では, 樹脂系カバー, ゴムカバー共に一長 一短があることを示した。

総合的な評価として, 低線压で同等の紙品質が得ら れるソフトロールの優位性が示唆された。

この発表に対して, ロール污れに対する洗浄方法に ついて質問があったが，どのカバー材質もドクター装 置では充分な粕除去ができず，人力によるサンドペー パーや水での掃除が余儀なくされている現状が説明さ れ, 今後の対策として粕剝離性の良好なカバー材質の 開発が必要であると強調された。

\section{A-3. 紙層構造と紙の品質について}

三菱重工業侏広島研究所 蓮池 牧雄

紙品質と抄紙過程の各種要因との対応関係について は今だ不明な点が多い。紙の高品質化・高生産性を目 指す上で, 経験や勘に頼らない抄紙コンセプトの構築 が急務である。そのためには紙層形成法を確立する必 要があり, アプローチの一つとして紙品質と紙層内繊 維集合構造（瀻維の分散性と配向性）及び集合構造と 脱水方式の関係について考察したものである。

前者に関しては, 紙の品質が表裏又は内部の紙層構 造に大きく左右されることを, (1)坪量変動と不透明度 の関係, (2)地合と透気度の関係, (3)紙の剛度の坪量依 存性, (4) $\mathrm{CD}$ 剛度と引張 $\mathrm{MD} / \mathrm{CD}$ 比の相関性, (5)伸縮 率表裏差と曲げ曲率の関係から解説した。

後者については, フォーミングプロセスをフォード リニアー, シューおよびロールタイプハイブリッド フォーマー, ツインワイヤーフォーマーに大別し, 各 フォーマーの脱水方式の特徵を総説した。加えて脱水 機構の違いからくる表裏間の紙層構造差を地合・空隙 特性・繊維配向特性の観点から解説した。

地合については, (1)透過光変動指数, (2)フロックサ イズ指数, (3)フロック濃度指数で説明し, トップワイ ヤーを有するフォーマーでのフェルト側の改善, ある いはシューブレードのパルス状圧力脱水が䋊維分散に 対して有効であることを示した。

また空隙特性いについては，(1)フレキソインキの付 着挙動, (2)同インキの浸透挙動で説明し, シュータイ プハイブリッドフォーマーの優位性を示した。

更に, ツインワイヤーフォーマーにおける繊維配向 特性を, (1)繊維配向比のジェット/ワイヤ一速度比に よる変化, (2)環境湿度変化に対するカール量で説明し た上で, これらを総合し, 今後ツインワイヤーフォー マーによって地合・配向度共に満足しうる紙が得られ
る可能性を示唆したものである。

(神崎製紙(㑣)當葥丁場 大西)

\section{抄紙セッションB}

司会 三菱製紙㑣パルプ技術部

部長 鈴木 正幸

\section{B-7。 サイズ剤・紙力増強剤の新技術}

ハリマ化成侏中央研究所 木村 吉晴

中性領域で優れたサイズ性を発揮する新規開発の特 殊変性ロジンサイズが紹介れれた。歩留も良好で，立 上り, 滑り等も改善されている。今後は高 $\mathrm{pH}$ 域での使 用量の減少に取組む。紙力增強剂としては, 古紙パル プの使用増やクローズド化等の悪条件ドでも安定した 紙力増強効果を発揮する新規な共重合物が紹介された。 高分子量であるにも拘らず，低粘度，低凝集性の特徵 を示し, 高歩留で抄紙条件の变動に対しても安定した 効果を示すものである。

\section{B-8． TOCL のすくない湿潤紙力増強㓮について}

サンノプコ(株研究部 竹下 和宏

市販のエポキシ化ポリアミド系湿潤紙力増強剤には 10\%以上の TOCL が含まれているが, 合成条件を変え ることによって TOCL 含有量 $0.5 \%$ 程度の新製品を 開発した。この新製品は広い $\mathrm{pH}$ 域に適用可能で, 繊維 への吸着性も優れている。抄紙工程における TOCLの 分布状況についても報告されている。

\section{B-9. 新規紙力増強剤一新ホフマン PAM}

三井東圧化学姝総合研究所 伊藤 博 高温域でのホフマン分解反応の検討を通して, 極め て短時間であれば，低温反応品以上の性能を有するホ フマン分解PAMの製造が可能であることを見出して, 最適設計されたベースPAM とそれを現場でホフマン 変性するシステムとを組合せた新ホフマン PAM を開 発した。この開発により, 経時劣化の問題の回避が可 能となり, 製造直後の高活性で高機能の状態を維持し た製品が得られた。活性が高いので, 定着が良く, ファ インの歩留や水切れが向上する。

B-10. インクモットリングとマイグレーションの関 係について

住友ノーガタック株ラテックス研究本部

石川 哲雄

RI トラッピング印刷によって, オフセット印刷時に 発生するモットリング現象を実験室的に解明出来る事 
を紹介し，でんぷん量，ラテックス量，塗液濃度等の 要因の影響に関する笑験結果と塗工層中のバインダー の分布状況の調查結果が報告された。

RI 印刷ムラは, 塗工一乾燥のインターバルの影響を 受けること，でんぷんの影響が大きいこと，ラテック スの選択が重要であること等を明らかにした発表であ る。

\section{抄紙セッションC}

司会 怢大昭和さいとう紙化学研究所 田中宏之

\section{B-11. 印刷適性向上薬品について}

BASF ジャパン侏）T.A.フォンバドカーシー 小林 千益

高歩留の機械パルプとその漂白パルプが開発されて その使用量が増加し，更にDIPの使用增と用水の節 約，白水のクローズド化によって木材抽出分やピッチ のような有害物質が高濃度化する結果, ウェットエン ドで使用する薬品の効果を変化させたり阻害したりす る現象を発生させている。これらの問題点の解決と, 更に薬品の定着性の向上，紙強度の改善や印刷適性の 改善などをもたらすようなプロセスの一つの方向とし て, BASFのポリミンとサイズ剤として PSA (Polymer sizing agent）とを併用することにより達成出来 ることを示す試験結果の説明がなされた。

実際のオフセット印刷機で生じる現象と類似させて, 紙表面の液体に対する短時間での耐水性を測定するた め, BASF Absorption Tester（BAT）を開発した。 この試験結果はオフセット印刷での印刷適性と良い相 関がとれており，ウェットエンドでの対応が最終使用 の場である印刷において，市場の要求する紙品質を満 たしているかの判定のために良い指標となることが分 かった。

\section{B-12.ローラロード“自動積載システム”}

$$
\text { ラムグレースハーバー社 ハル・アーノルド }
$$

伊藤忠商事(侏) 平賀 直樹

現在の製紙工場内はハイテク機器により可成りの部 分が自動化され, 高能率化, 省力化が計られているが, 製品含庫からの入出荷部は自動化されない部分として 残されているのが現状である。

ラムグレースハーバー社は自動積載システムを開発 して，この部分を自動化したことで1つのドックが 1 時間に 8 台のトレーラーの発着を可能にした。このシ ステムは倉庫内のレール上であらかじめ 1 台分の製品
を準備しておき，ドックに入ったトレーラーと特殊な 方法でドッキングさせ，一気にトレーラーに積み込む 方式である。このシステムを導入する為には, 次のよ うなファクターを検討することが重要である。

(1)自動積込み積みおろしに適した荷物か，(2)自動積

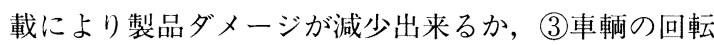
率が重要か，(4)トラックまたはトレーラーは専属か, (5)現在のドックに自動積載システムをつけてコストメ リットがあるか，(6)ドックにはこのシステムに使われ る車輛以外の車輛が入ることがあるか等である。

効果的にこのシステムが使われるならば，必要な ドック及び関連設備，リフトトラック及びその関連コ スト，車輛の回送時間等を減じる効果と共に，製品の 荷傷みを最少にすることができると言う。

B-13. バキュームロールリフターによるロール自動 倉庫

(株丸石製作所技術開発室 古賀 孝好

昨年，技術提携したドイッのバルトロミー\&カンパ ニー社のドイッを中心にヨーロッパで実績のあるバ キュームロールリフターによる倉庫の有効利用の技術 について紹介があった。この方式は天井を走行するリ フターにより真空で巻取を把持する方式であるが，把 持出来る最大巻取重量は $12 \mathrm{t}$ (外径 $2,500 \mathrm{~mm}$, 幅 $2,850 \mathrm{~mm})$ で, クランプ方式に比して巻取の平面上で の配置を接近して置けるので，一般的には $13.6 \%$ 多く 置くことが出来る。システムとしては,バキュームロー ルリフター, クレーン及びクレーンコントローラー, ロール搬入排出コンベア，倉庫管理用コンピューター, 建屋及び附带設備となっており，フォークリフト通路 も不用となり，最大高さ $11.4 \mathrm{M}$ の実績が示すように スペース効率の良い自動倉庫を構築できる

ドイッ Feldmühle 社の実施例により, 実際の操業と 経済効果まで説明が行われた。現在の所，包装紙で全 面を覆われている巻取の積み上げについては研究開発 中とのことであり，今後に関心がまたれる。また地震 などによる安全性については充分検討がなされている とのことである。

\section{B-14. 新ワインダ“デュオローラ II”}

石川島播磨重工業㑣紙パルプ機械第一設計部

田中 貞一

印刷業界では印刷の高能率化指向から，コート紙， 軽量コート紙, 新聞用紙等の巻取大径化, 広幅化への 要求が高まっているが，これに対応した新しいワイン 㚈が開発された。巻取径 $1.5 \mathrm{~m}$, 製品幅 $3.5 \mathrm{~m}$, 最大巻 
取速度 $2,500 \mathrm{~m} / \mathrm{min}$ が可能であり, 作業性と同時に巻 取品質の向上に留意した設計となっている。

基本的な構造として，1本のセンターロールと 2 本 のサイドドラムによる 2 つのインディングニップを 有し, 通紙の自動化, ワインダの運転, 巻取硬さのコ ントロール, 巻取自動枠替, スリッターやリワインド ステーションの自動位置替等の他に, 生産データの記 録と整理を含む新開発のコンピューターシステムを包 含する。これらの新機構により, これまでの 2 ドラム ワインダの唯一の欠点であった巻取径の限界を突破し, なお大径化による重量増に対し, 従来使用されている 内径 $76 \mathrm{~mm}$ のボール芯で充分使用に耐えるものと なっている。機構上センタードライブが不要であるた め, ボール芯に対し据り応力の発生がないことは, 巻 取の芯部と外層部の硬さが一定に出来ることと共に, 品質上の大きな利点となっている。

$$
\text { パルプセッションA }
$$

司会山陽国策パルプ(株)研究開発本部 本部長代理 山口章

\section{A-4. カミヤ連釜におけるブローK 価の最適化制御} について

一釜の状態解析と Hatton 式の応用一 神崎製紙(株)富岡工場 多田 友紀, 中山 崇文

\section{横河電機(株) 西村 淳}

富岡工場の第 3 系列の KP 連金をスタートさせるに 際して，金の制御に横河電機株製のプロセスコン ピューターと上位コンピューターを導入した。

金ブローK価のコントロールに上位コンピューター を使用し, 原理にHattonの式を応用し，その有効性を 検討しな。具体的な検討としては, (1) Hattonの式の適 性確認テスト, (2)コンパクションファクターの設定, (3)オンライン K 価計の精度, (4)実機での制御の確認テ ストを実施した。なお，コンパクションフアクターの 設定は実機およびラボテスト，さらに物質支収からの 考察によっている。

検討結果として, Hattonの式はバッチ蒸解や連金 での生産量変更時に有効な目安となることを実証して いる。本システムの有効性を保持するには，チップの 配合の均一性確保, チップ水分の自動測定, 液比のコ ントロール，ストレーナー詰まりの未然防止等の課題 があり，それらの解消を図って，プロセスコントロー ルを前進させて行きたい。その手段として上位コン ピューターは大きな武器となると確信している旨報告
された。

\section{A-5. 新ポリサルファイドプロセスの操業経験 三菱製紙(株白河工場 原普一}

三菱製紙(株)と千代田化工建設(株によって開発された ポリサルファイド蒸解プロセスの第 2 号機が 1990 年 4 月に八戸工場に導入され，その導入経緯と操業経験 が報告された。

操業経験として, (1)設備の運転状況, (2)蒸解工程, (3)漂白工程, (4)回収工程, (5)パルプ品質, (6)パルプ収 率，(7)臭気と腐食問題，8プロセス導入による経済効 果等の項目について実機での結果が述べられた。

結論として，次の 5 項目に整理される。

(1) ポリサルファイド蒸解プロセスは導入後順調に 稼動している。

(2) 本システムによって約 $1 \%$ のパルプ収率の向上 が得られた。

(3) その他の効果として, 収率向上に伴う回収ボイ ラーの負荷の軽減と，木鉒でのアルカリ使用量の 減少に伴う苛性化工程の負荷の軽減であり，パル プの増産が可能となった。

(4) パルプ品質に差は認められなかった。

(5) 本システムの導入による経済性としては，十分 に採算があることを確認した。

この報告について，パルプ収率の確認方法，特にパ ルプ中の糖組成の意義,・臭気問題の氈念について質疑 応答があった。

\section{A-6． 漂白ショートシーケンスの操業経験 \\ 十條製紙(株八代工場 今野 武夫}

1989 年 3 月に $550 \mathrm{t} / \mathrm{d}$ の $\mathrm{KP}$ プラントを新設したが, 設計段階で, (1)省設置スペース, (2)用排水などの環境 保全, (3)省力的な設備等を考慮して中濃度酸素晒 $\left(\mathrm{MC}-\mathrm{O}_{2}\right)$, 加圧型ドラムウオッシャー, ディフュー ザーウオッシャー，そして 3 段漂白法 (CD)-(EO)-D のショートシーケンス漂白を導入した。

本報は(1)設備概要, (2)漂白シーケンス選定理由, (3) 操業状況と品質について述べられ, 特に操業経験では, (1)用排水, (2) $\mathrm{MC}-\mathrm{O}_{2}$ 晒, (3)漂白センサーと薬品添加管 理, (4)漂白条件とパルプ品質, (5)スケールトラブルに ついて詳説された。

むすびとして，今回採用のショートシーケンスは， 現在, 設計值を越える $600 \mathrm{t} / \mathrm{d}$ ベースで安定操業を続 行している。設計段階で考慮した前記目的は十分満足 な結果をえている。このショートシーケンス漂白にお ける重要なポイントとして, 前段の酸素晒で出来るだ 
け脱リグニンを進め, カッパー価を 11 以下とするこ と, 未晒および晒両工程での洗浄を適切に行うことの 重要性を強調。これらは操業, 品質の安定のみならず 環境保全の面においても重要であると報告された。

\section{A-7． 2 段中濃度酸素晒設備について}

\section{王子製紙侏技術本部技術部 近藤晋一郎}

同社の酸素晒設備の導入の歷史は, 1985 年の苫小牧 と江別工場に始まり，1990 年カナダの関係会社，1991 年の米子工場, 本年 12 月稼働の日南工場を含めると全 $\mathrm{KP}$ 工場に酸素晒設備が設置されることになる。

これら 7 工場とも 2 段中濃度酸素晒設備であり, 本 設備の開発経過および操業状況が報告された。

開発経過としては, 設置した1段酸素晒設備で目標 としたカッパー価の低下が得られず，その原因究明と 問題解消を目的にテーブルテストと実機テストを実施 した。その結果, 酸素晒塔に $\mathrm{MC}$ ミキサーを経由して 供給される酸素の微細粒子は比較的短時間で集合して しまい, 脱リグニン反応は停止してしまう。それを解 消するには, 酸素が集合してしまった時点で再度ミキ シングして残存酸素を再分散させる方法が効果的であ るとするものである。

操業経験として，2段酸素晒にすることにより，晒 条件にもよるが, 春日井工場の操業実績では N用設備 で $\Delta \mathrm{K} \alpha 52 \%$ ，L用設備で $\Delta \mathrm{K} \alpha 43 \%$ あ゙る。

晒条件（アルカリ・酸素添加率）と $\Delta \mathrm{K} \alpha, \Delta$ 粘度の 関係が詳説されている。

\section{กากา パルプセッション B \\ 司会 中越パルプ工業森工務部 \\ 技監 平井 誠也 \\ B-1. 化学エ学的アプローチによる新規脱墨㓱の開 発}

ライオン(株)化学品事業本部 田井 雄二

脱墨剤の開発において従来はともすれば界面化学的 アプローチに重点がおかれるきらいがあったが，ライ オン侏では最近発達した処理技術に着目して, 処理装 置の機能との適合性を加味した実験方法と評価方法を 編み出した。例えばパルパーに於いては離解エネル ギーの概念を導入することにより，実機とテーブルテ ストとの相関が良くなり新規脱墨剤の評価精度が高く なった。フローテーターの場合は(1)混合度, (2)パルプ スラリーの平均滞留時間, (3)気液比, (4)気泡径の 4 つ の指標を考えこれらを実機と実験機で同じ值になる ように設定して脱墨剤を評価することにより新製品の
開発に大きく寄与している。

\section{B -2. 進化する DIP 技術}

石川島産業機械(株)原質機械営業技術部

岩重 尚之

DIP の製造技術に対する 1 つの提案を行っている。 新聞古紙の脱インク工程では離解・粗選後にパルプを 25 30\%に濃縮してインクの剝離，パルプの漂白を行 うシステムが一般的となっているが, その際, 発生す る白水は循環使用し完全クローズドにすることが多い。

そこでこの白水中の微細成分が過酸化水素を大量に 消費すること, フローテーションでの除去を困難にし ていることを実験的に確認すると共に，これを防ぐ方 法として粗選工程中に微細成分を除去する操作を入れ た場合にインクの剝離と漂白効果が著しく向上するこ とを見出し, その設備としてNNTウオッシャーと MT フローテーターが有効であるとしている。

\section{B-3． 板紙古紙処理の集中テール処理の経験} 一超高濃度ミキサーパルパーの応用例— 相川鉄工株技術部 青嶋 和男

（1）板紙古紙処理の集中テール処理の経験

古紙処理プラントから廃棄される粕の中には未離解 片や有効繊維分をかなり多く含んでいるので，これを 回収するためのシステムを紹介している。ここでは 3 つの例を紹介しているが，大別するとアルカリ熟成を 行うものと行はないものがある。いずれの場合も粕を 先ずミニトロンメルで予備脱水し傾斜スクリューで約 $15 \%$ に脱水する。苛性処理はその後行い, クリーナー やスクリーンで除塵するが, 菏性処理を行はないもの は傾斜スクリーンの後, 高濃度パルパーで離解する。 更にその後でクリーナー，七パレータ，スクリーン等 で除塵する。このシステムにより品質の高い DIP を高 歩留で生産することが出来た。

(2) 超高濃度ミキサーパルパーの応用例

通常製紙用パルパーは低濃度用 $(2 \sim 6 \%)$ から高濃 度用 (12 16\%) が使用されているが，30\%以上の超 高濃度領域のパルパーは叙使用されていなかった。 今回は $40 \%$ 以上の濃度で離解を可能としたミキサー パルパーについての紹介である。構造としては傾斜し た円筒形夕ブとその中央に位置するローターから成り, お互に逆方向に回転する。既に 13 台の実績があり, 日 本では大蔵省印刷局に 1 台納入されている。ポリラミ ネート古紙等にも実績があり, 今後多方面での応用が 期待されよう。 
B -4. 新しい無機系ピッチコントロール剤

水澤化学工業(株)研究開発本部 阿部潔

最近開発された酸性白土（アルミノケイ酸塭）系で 画期的なピッチコントロールの紹介である。シルトン LP 系ピッチコントロール剤は酸性白土を化学処理, 物理処理によりピッチの吸着性能を強化改質したもの で，その特長はピッチの吸着量が夕ルク系のそれと比 較して 3 倍の能力をもち, $\mathrm{pH}$ 依存性がすくなく, 不透 明性が高いので内填剤としての位置付けも可能である。

\section{B-5. パルプの酵素による改質}

一ベッセレックスによるベッセルピック対 策一

\section{合同酒精(株)中央研究所 石崎 晴記}

本州製紙(株)と共同で開発された酵素（セルラーゼ： ベッセレックス）によるベッセルピック対策法の紹介 である。ベッセレックスを $0.1 \%$ パルプに添加して叨 解するとフリーネス $450 \mathrm{ml}$ でベッセルピックが無添 加の場合の約 10 分の 1 以下に減少した。同時にパルプ の改質効果として(1)未叮解フリーネスが上がる(2)裂断 長, 耐折強度など物理的強度が向上する(3)平滑度が向 上する(4)不透明度が低下する等が確認された。

\section{B-6. 酵素によるピッチコントロール \\ 一ピッチコントロール用酥素剤 “レジナーゼ” の利用一

$$
\text { ノボノルディスクバイオインダストリー(株) }
$$

\section{応用技術部 下戸 秀聡}

十條製紙(株)と共同開発された酵素（リパーゼ：レジ ナーゼ）によるピッチトラブル対策法の紹介である。 レジナーゼ A 2 X は液状の脂肪分解酵素であり，広範 囲の温度, $\mathrm{pH}$ 領域にわたって効果をあらわす。レジ ナーゼはその希釈溶液をパルプスラリーに添加するこ とによりトリグリセライドを選択的に分解する。工場 操業ではGP ラインのポストリファイナー前で添加す ることにより, 紙面のピンポールの数を 1 日あたり 80 倜から 19 個に減らすことが出来な。

\section{総合技術セッションA}

司会 北越製紙(侏技術開発部 技術担当部長 安達隆

A-8. エキスパートシステムによる生産計画システ ム

王子製紙侏苫小牧工場 安田 保彦 生産計画エキスパートシステムについての概要及び
効果などについて紹介がされた。

苫小牧工場に於るミルワイドシステムの構成（亡場 統括, 部門総合管理制御, 工程制御の冬レベル), 導入 目的, 概要, 生産計画作成システム (大枠配置, 詳細 配置, 置換え処理の各エキスパートシステム), マンマ シン機能, 支援システム, 等々が詳細に紹介され, 工 場の生産計画作成業務の効率化とレベルアップに大き く貢献していること, コンピューターシステムを構築 していく上での注意事項も合わせ発表された。

\section{A-9． 苛性化ロングキルンの操業経験}

\section{一北越新潟D系キルンについて一}

北越製紙(秼)新潟】場 新野 朋夫

新潟工場湿式ロングキルンの設備概要, 操業状況, 運転自動制御に関しての報告がされた。

設備概要：苛性化キルン設備, センサーの紹介

操業状況: 生産能力, 重油・電力原単位, ライムマッ ド性状, 排ガス性状, ダムリング等々いずれも計画傎・ 保障值に対して充分に満足していることが紹介された。 制御について：重油自動点火, 穼尻 $\mathrm{O}_{2}$ 制御, プレ コート自動更新, 自動引き抜き制御等々の自動制御に より当初の目的はほぼ達成されている。

\section{A-10．循環流動層ボイラーの操業経験}

本州製紙(侏釧路工場 奥村 広司

ボイラー燃料の重油から石炭への転換，近年，工場 で問題が顕在化してきた製紙スラッジの処分及び $\mathrm{SO}_{\mathrm{x}}$ をはじめとする低公害性等に着月して導入され た循環流動層ボイラーが完成したので, その操業経験, 概要が報告された。

火力発電所の概要 :

特徵：循環流動層ボイラーは気泡型と気流搬送型と の中間に位置し, 熱交換性が高い, 効率が高い, 炉内 脱硫可能, $\mathrm{NO}_{\mathrm{x}}$ が低い。

ボイラ仕様：

運転実績：高負荷連続運転に努力した結果, ほぼ当 初の目標を達成出来た。

安定運転に必要な条件として, 炕内温度制御, コン バス夕ー差圧 (火炉の安定燃烤), 投入燃料の大きさと スラッジ類の安定供給が挙げられる。

環境規制值と排出実績：計画性を大きく下まわり満 足されるものである。

運転開始後の主な改造項目: 流動灭循環率のアップ, 火炉管の流動灰による磨耗

今後の課題：伝熱管の磨耗対策, 効淬的機器補修, 省エネ運転等々貴重な経験報告がされた。 


\section{A-11。紙パ工場の産業廃棄物の実態調査}

\section{（環境技術委員会廃棄物調査担当）}

大炤和製紙(㭌)環境保全室 高橋澄 北越製紙(㑣)技術開発部 立石 寛文

最近, 地球環境への関心が高まり, 廃棄物処理も大 きな社会問題として提起されている状況から, 産業廃 棄物の笑態について，アンケート調查を実施し，その 中間報告である。また，どの様に状況が推移したかを 見るため,

前回 昭和 57 年 4 月～昭和 58 年 3 月

今回平成元年 4 月～平成 2 年 3 月

の対比も行っている。

調査項目は

1. 産業廃棄物の排出・保管 - 処分, 有效利用の状況

$1 \cdot 1$ 廃棄物の種類別分類による状況

$1 \cdot 2$ 保管・最終処分方法別分類に上る状況

$1 \cdot 3$ 保管, 最終処分, 有効利用の単価について

$1 \cdot 4$ 産業廃集物の有效利用の状況

$1 \cdot 5$ 製品種類別.T場分類による状況

$1 \cdot 6$ 白社管理の最終処分地の状況

2. 脱水機の状沙

$2 \cdot 1$ 脱水機の種類別設置台数について

$2 \cdot 2$ 設置年次別分類

$2 \cdot 3$ 処分能力

$2 \cdot 4$ 所用電力

$2 \cdot 5$ 脱水機の使用状沉

3. 焼却炉の状況

$3 \cdot 1$ 焼却邩の設置状沉

$3 \cdot 2$ 運転状況

$3 \cdot 3$ 原単位

$3 \cdot 4$ 熱回收

と公範囲にわたっている。

産廃物の処理が年々缓しくなる為，廃竦物の発生を 抑えると共に份效利用の可能性を少しでも探究し，利 用先のニーズに命わせて有効利用を增加させる必要が あること。今後, 予想される処分費用の高騰, 処分用 地の確保闲難，発椠物処理関連法規の規制強化等を考 えると，今後は烓却処理率が增加するものと思われる。 なお，本報の詳紐は後日，紙パ技協誌に報告される 予定。
総合技術セッションB

司会 紀州製紙(秼)紀州工場工務部 技術課長 歯梁尾紘治

B-15． アプローチシステムの将来展望 一デキュレータークリーナーの歴史一

日本ユーエスマシナリー(株)

営業技術部 永澤 宏之

ストックインレット・アプローチシステムの要件は 原料流の物理的・化学的安定性とシステムの清浄性を 維持しつつ，いかに脱気を行うかということである。 スタッフボックス, ワイヤーピット, キャナル, 白水 サイロもこの観点から設計される。原料中に存在する 空気は“自由空気”，“残留空気”，“溶存空気”に分類 されデキュレーター・クリーナーはこれらを除去する ことができる。完全脱気を行うには“真空”，“噴霧”， “衝突”の条件が揃うことが必要である。

デキュレーター・クリーナーの変遷は次の通りであ る。

低置式デキュレーター：マシンフロア上に設置。 オーバーフローポンプが必要である。

高架式デキュレーター：白水サイロ液面から 10.5 $\mathrm{m}$ 以上:の高さに設置。オーバーフロー液面はバロメト リックレグとオーバーフロー配管の圧力損失によって 決まる。

フライング・ウイング型デキュレーター：小ロ径ク リーナーを多数使用の場合，ウイングと称する大径管 にクリーナーを取付け，レシーバーの両側に翼の様に 延ばしたタイプである。

多重管方式オーバーフロー円筒堰：1枚板の堰板の 代りにレシーバー内に円筒形の堰を設けテーパー管で 直接オーバーフロー配管につなぎ，更に内側に内筒を 設けた物である。オーバーフローの脈動が非常に少い。 スペース・セーバー型デキュレーター：据付面積は 従来型に比べ $3 / 4 \sim 1 / 2$ のスペースで瑶む。フィード・ チャンバー, リジェクト・マニホールドは端末のない ループ状となっている。

\section{B-16. ウインベルトワインダ}

一大径ロール巻取用新型ワインダー

住友重機械バルメット侏技術部 冞川 博親

ウインベルトワインダはツードラムワインダの持つ 高い運転效率を生かしつつ, シングルドラムワインタ 並に高品質な巻取ができる新型ワインダを目指して開 発された。1988 年初号機稼動以来, 新聞, LWC, SC 紙向に 7 台が稼動，1台が建設中である。 
主な特長は次の通りである。

・巻取ロール自重の影響を受けずにほぼ一定の巻固さ を得ることができる。

・巻き始めを硬く，巻き終わりを柔くという理想的な 巻取りができる。

・線圧による巻固さの増加が少く, 全巻取径において トルク差制御を有効に使う事ができる。

・フレームは高剛性で最高 $2,500 \mathrm{~m} / \mathrm{min}$ 迄の巻取り が可能である。

・自動セットチェンジ等の機能を有するのでッードラ ムワインダ並の運転効率を得る事ができる。

・最小取り幅 $150 \mathrm{~mm}$ の巻取も可能である。

基本構造は, ツードラムワインダとほぼ同じである が, ワインディングセクションが異る。リアドラムは 同じであるがフロントドラムの代りに 2 本のベルト ロールに支持されたベルトベッドを使用する。巻取 ロール重量の大半は幅方向に連続して並べられたベル トで支持される。従ってリアドラムには極く一部の重 量しか作用せず，自重線圧は極めて低く押える事がで きる。

なおべルトの寿命については, 新聞用紙用として 1 年以上の実績があり実用上問題の無いレベルに到達し ているとの事である。

\section{B-17. スーパーカレンダー用樹脂ロール ーエラグラス ZE-}

(株)金陽社 山田 和夫 スーパーカレンダーに樹脂ロールを使用した場合の 問題点として

・耐圧性, 特にクイーンロールとして使用した場合

・断紙時などの紙の巻付きによる傷付き

・ロール表面への塗工鼡, 紙片等の付着による傷付き があるが,これらの問題点を解決したのがエラグラス ZEである。硬さはショアーD 91 と 94 の 2 種類あり耐 熱性に優れた特殊樹脂を使用しているので，ガラス転 移点が $183^{\circ} \mathrm{C}$ と高く高温使用できる。

回転特性としては線圧 $350 \mathrm{kgf} / \mathrm{cm}$, 回転数 150 RPM, 1 ニップ, ヒートロール温度 $120^{\circ} \mathrm{C} \sim 200^{\circ} \mathrm{C}$, エ ラグラス ZE ロール温水冷却の条件で表面にへアク ラックなどの問題は発生せず高温 $200^{\circ} \mathrm{C}$ をクアして いる。またヒートロール温度 $80^{\circ} \mathrm{C}$, 回転数 $200 \mathrm{RPM}$, 2 ニップ, 線圧 $500 \mathrm{kgf} / \mathrm{cm}$ でもロール表面に全く異常 無く $500 \mathrm{kgf} / \mathrm{cm}$ の線圧をクリアしている。

スーパーカレンダーの使用条件である「相手ヒート ロール温度 $60^{\circ} \mathrm{C} \sim 100^{\circ} \mathrm{C}$, 線圧 $200 \sim 400 \mathrm{kgf} / \mathrm{cm}$, 回転 数 $400 \mathrm{RPM}, 2$ ニップ」のロール回転試験では, ヒ一
トロール温度 $100^{\circ} \mathrm{C}$, 線圧 $350 \mathrm{kgf} / \mathrm{cm}$ までは問題無 く, 線圧 $400 \mathrm{kgf} / \mathrm{cm}$ の条件でロール表面にへアク ラックが入ったとの事である。一般的なスーパーカレ ンダーの使用条件はヒートロール温度が $80^{\circ} \mathrm{C}$ 以下, 線 圧 $250 \mathrm{kgf} / \mathrm{cm}$ 以下なので十分に使用できるとの事で 2 社での使用例の紹介があった。

\section{B-18. 紙パCIMにおける操業意志決定支援システ $ム$}

横河電機㑣プロセ又第二営業本部 富士 薰晴 紙パルプ工場の CIMの1つの形態としてミルワイ ドシステムの導入が進められてきたが，基本的にはこ のシステムは CIM 化の中では操業管理レベルを包含 した形での生産管理レベルのシステムである。

工場全体のシステム統合化には, 生産管理系からの アプローチと, DCS によるプロセスオートメーション を基盤とした操業管理系からのアプローチがある。こ の 2 つのアプローチには機能上の境界面が存在する。 この境界面に求められる機能をよく整理し, 新しい操 業支援機能の展開を目指すために, DCS をべースとし た操業意志決定支援システムが必要と考えられ，この 面からのアプローチが行われている。

操業意志決定支搤システム (MDSS) はPA・FAの プラットホーム上に構築されて制御レベルと情報レべ ルの中間に位置付けられ, 操業管理者の意志決定業務 支援を目的としている。

MDSSにおける操業指針決定のための「目で見る管 理」を構成する機能は大きく 2 つに分けられる。

・下位レベルの管理機能

稼動状況, イベント管理, 進捗, 品質及び実績管 理

・上位レベルからの情報受信機能

指図, 在庫, 技術基準值及び他部門からの情報を 受け操業管理者が活用できるデータ加工

これら MDSSの各種機能要素は汎用的なパッケー ジとして標準化され信頼性の高いプログラムとして提 供されている。MDSSの構築により, 垂直方向の情報 伝達を整理し, 既存の生産管理システムとの結合にも 柔軟に対応できるとの事である。

\section{B-19. プロセス産業の CIM 化（P-CIM） -TDCS 3000 EXPERT/EVENT HIS- TORY-}

山武ハネウェル侏計装技術部 進藤 文夫

製造業を取り巻く環境は大きく変化している。この 変化への対応策として CIM が脚光を浴びている。顧 
客が要求する製品を生産する形態へ移行し, 開発期間 の短縮, フレキシブルな生産体制といった機能が CIM に要求される。一般に CIM はFA より概念が広く, 情 報が主役となって企業全体の活動を統合する位置付け となっている。研究開発, 生産, 販壳という会社業務 を有機的に結合して，1つの経営戦略のもとに動かし ていくシステムと考えられる。

TDCS 3000 をべースとして築かれたプロセスCIM (P-CIM) は, プロセス制御と生産管理システムを結合 したものである。特長は次の通りである。

・見えるシステムである。

生産システムの状況をリアルタイムで, 何時でも 誰でも，何処でも見える様EVENT HISTORYを 開発した。

・ダイナミック生産システムである。

運転管理のシステム化を四るため, オペレータの 運転, 操業上の知識をルール化し, 迅速な対応がで きる様 TDCS 3000 EXPERT を開発した。

・インフラ・ストラクチャの下記基盤が必要

(1)新旧システムの統合 (エボルーション)

(2)フィールド計器のスマート化とネットワーク化

(3)他社システムとの結合

(4)データ・アクセスの一元化

\section{B-20. 紙パCIM のねらい所と事例紹介}

(制東芝産業システム技術部 岸田 雅大

CIM の機能構成を業種別に比較すると, 紙パは基礎 資材 (新聞用紙, 板紙, 印刷用紙), 一般消費材 (家庭 用紙) の両商品体系が混在する業種である。CIM では 市場とのかかわり方，マーケットインの接点がどこに あるかを見定めることが大事で，紙パは鉄・化学と同
様に見込受注型である。完全な受注方式に比べて短い 納期対応が, また完全な見込方式に比べ軽い在庫負担 で済む中間的な業態である。

従来から進められてきた情報化投資は, 情報システ 厶部門主導の管理側からのものと, 工場設備部門主導

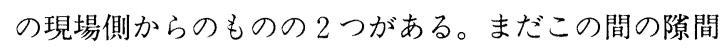
は埋められていない。現場管理者の人間系に頼ってい るのが実情で，市場の変動に対する柔軟なオンライン 対応がしきれていない。24時間オンライン要求の強い 生産現場と営業現場が直接りンクされ，どれだけ生き た情報を通わせあえるかが差別化のポイントとなる。 従来, 手書き・人間系によっていた各部門管理者の頭 の中にあった人間系管理方式ノウハウを整理し, 標準 化, ルーチン化し, 計算機上に焼直し, その支搤ツー ルを用いた管理方式に切替えていく。最終的には各部 門毎に, 統合管理を行う計算機を設置し CIE 統合管理 システムを整備していく事が必要になる。各部門の製 造・品質のリアルタイムデータベースが, CIM 化を進 めていく上で次の 3 本の情報パイプの発進基点になっ ている。

(1)各工程部門間の情報連携

(2)研究開発一生産部門の連携による商品開発の効率 化

(3)営業現場一生産現場の生販情報リンケージ

この生産現場のリアルタイムデータベースと, 営業 現場がダイレクトリンクされると, 生販統合 CIM の展開が進んでいく。

事例紹介は王子製紙(侏)苫小牧工場の例と最近の新設 マシンの CIE 統合製造管理システムの例について説 明があった。 